\title{
REINFORCED CONCRETE + MASONRY: THE 'MIXED' STRUCTURE OF THE NOVOCOMUM BY GIUSEPPE TERRAGNI
}

\author{
ANNA GREPPI ${ }^{1 *}$, CAROLINA DI BIASE $^{1}$ \\ ${ }^{1}$ Department of Architecture and Urban Studies (DASTU) \\ Politecnico di Milano \\ Via Bonardi 9, 20133 Milano, Italy \\ e-mail: \{anna.greppi, carolina.dibiase\}@polimi.it, www.dastu.polimi.it/ (*corresponding author)
}

Keywords: Novocomum, 'mixed' structure, structural components, archival research, digital imaging

\begin{abstract}
With his design of the Novocomum building in Como (1928-29), the famous first example of Rationalist architecture in that city, Giuseppe Terragni began to experiment with a mix of different architectural languages and construction techniques. Within the space of less than a year - from January to October 1928 - Novocomum saw a shift from the traditional to the innovative. Starting out with a weight-bearing structure of brick walls, the development of the project led to the introduction of reinforced concrete, which however did not entirely substitute the former: by 1929, such 'mixed' structures were to be seen in many buildings then being created and might be taken as a hallmark of the various forms of so-called Italian modernisms. Within the enclosed building site, work on Novocomum preceded right up to the terraced roof, and would only be unveiled to the unsuspecting citizens of the city once completed (1930), giving rise to a fierce controversy. The paper here proposed draws upon wide-ranging research into the Novocomum project to offer material of great significance for our understanding of the characteristic features, methods and phases of construction work - all aspects that have received little attention in the many studies dedicated to Terragni's architecture. The research made ample use of the documents now conserved in numerous public and private archives in Lombardy, continually comparing the information therein with the building as it stands nowadays. There was a focus on documents relating to work on the building site, which record each successive phase in construction. This material included: notes, technical drawings, estimates of costs, work reports, calculations, payment records and letters, as well as the documents relating to the tense dispute with the building contractor which involved the architect's brother, the engineer Attilio Terragni. A systematic analysis of the data thus gathered made it possible to reconstruct the far from straightforward interweave between the different phases in the building's construction and the various ideas advanced in the project designs. Furthermore, study of the structural aspects themselves could draw upon a 3D graphic model, which made it possible to assembly and dismantle the various parts of the structure and thus understand the articulation of the building more fully. At the same time, study of how the various building materials were used provided a further key to understanding the different components of the weight-bearing structure. Comprising an analytic assessment of the material collected, the study aims to be an important source of knowledge for future research into issues
\end{abstract}


related to the structural behaviour and durability of the building.

\section{INTRODUCTION}

The issue of housing was of central importance to modern architectural research in the 1920s and 30s. This was a period when experimentation with new types of materials and new systems of construction resulted in developments in both design and building techniques. [1] And a decisive factor here was the use of structures in reinforced concrete.

Within Italy, structural components in reinforced concrete did not entirely replace walled structures but were gradually combined with them, resulting in the 'mixed structures' adopted in the still largely traditional construction sites which existed in the period between the two world wars. [2].

A significant example of this phenomenon, the Novocomum building (Como, Lombardy, 1927-30) directly reflects developments in contemporary European architectural design - in particular, within work by the leading figures of the Modern Movement, to which Giuseppe Terragni belonged.

By the time he graduated from the Politecnico di Milano in 1926, the young Terragni (190443) was already challenging the historicist tendency that was so dominant in the teaching of architecture. And in his first important work in Como - a building of apartments with a ground

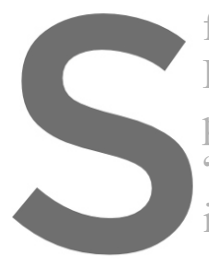
floor partly given over to office space - he
Rationalist architecture in clear contrast to the
preceding designs for the building. As he hi
"Starting from the premise that, as a result of rat
in architecture emphasize simplicity of line, construction, and highty-developed service facilities [...] this proje

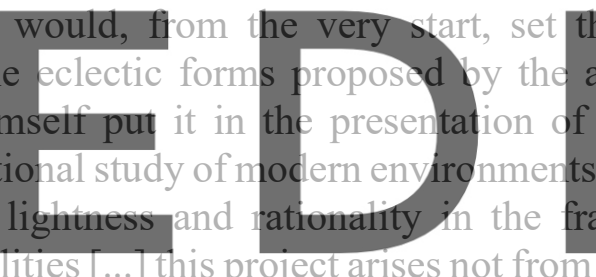
of pointless ornamentation but from the composition of a few, finely-finished, materials, and

Nevertheless, his initial designs were for a traditional brick-built structure of six floors (above ground levei), which ran in a straight line along Via Sinigaglia and was defined by the use of cylindrical volumes at the corners.

The whole Novocomum project was far from straightforward, and right from the very earliest stages one can see continual modifications. In part, these responded to functional needs, reflecting Le Corbusier's notion of housing as a machine-à-habiter in which each part performs to a precise purpose; in part, they reflected the "rational study of modern environments." [3] Ultimately, these modifications also included the adoption of structural components in reinforced concrete, while nevertheless maintaining part of the solid-brick structures that had been envisaged in the initial designs. Within Terragni's studio, it was his brother Attilio - in later years the podestà [the mayor, in the fascist period] of Como - who was responsible for structural planning.

Various studies of Terragni's work have offered chronologies and interpretations of the sequence of plans drawn up for the Novocomum project. $[4,5,6,7,8]$ And in a recent research project concerning the construction of Novocomum and the alterations it has undergone over time [9], the already-published material was compared with further visual documents (studio 
designs, intermediate versions) that were interpreted in the light of material that had yet to be fully explored (including the instructions drawn up at various phases in the construction work). Most of the drawings consulted in that research (the basis of the present paper) can be dated over the period from 1927 - when Giuseppe Terragni received the commission for the project - to 1929. And it is precisely the dates of these drawings and designs which, together with the dates of the different phases of building work, reveal how the changes in the project design were bound up with the development of the on-going construction; how the chronology of the solutions proposed overlaps with that of the building work. This was true right up to the completion of the project, even if it is also the case that the final versions of the designs do not correspond fully to the structure as built. The study and organization involved documents from many public and private archives - first and foremost, the archive of the Terragni studio - made it possible to reconstruct the complex history of the design and of construction work. 3D graphic reproductions were created to study the relation between the various components of the structure.

\section{THE STRUCTURE OF NOVOCOMUM}

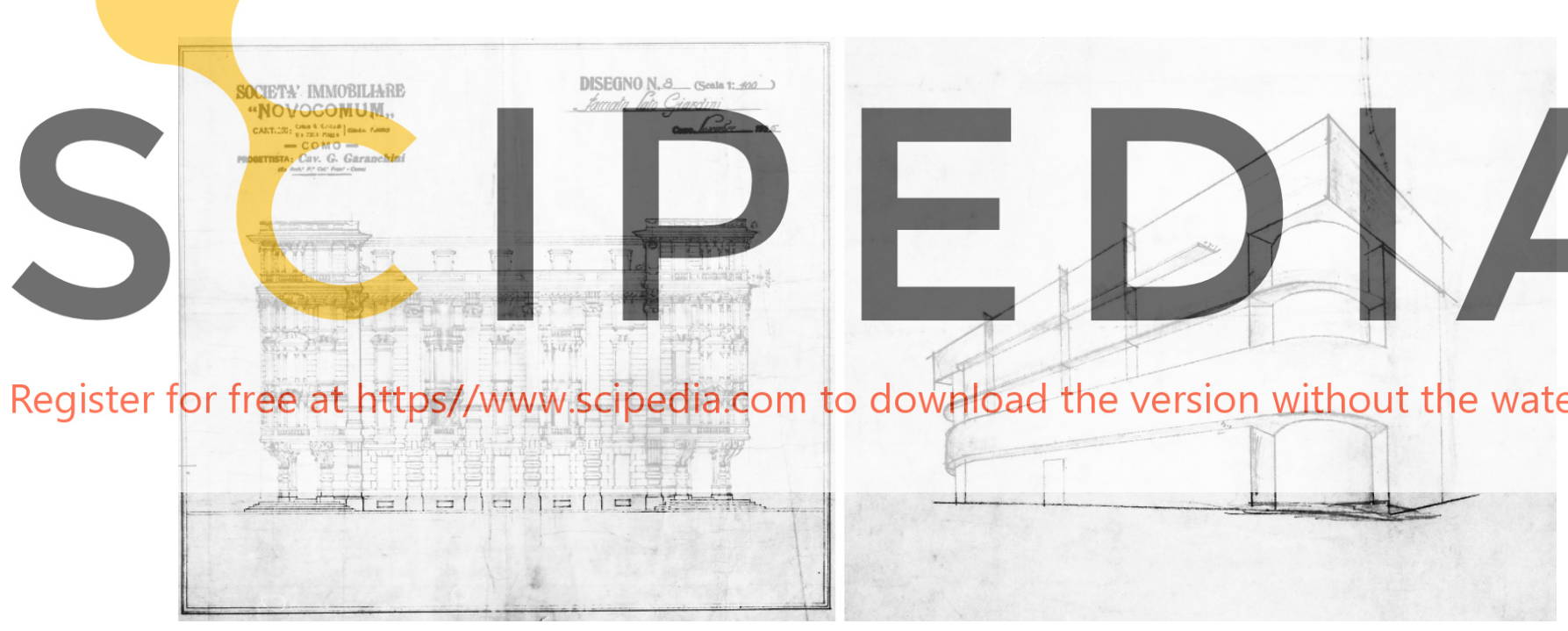

Figure 1: Project for the building in Via Sinigaglia (Como) which was intended to occupy the entire city block, elevation, G. Caranchini, November 1925, Terragni's studio Archive (ATCo), 6/016/B2/S/E, on the left;

"Maison de rapport Novocomum", sketch of the elevation, signed, 1929, ATCo, 6/005/D1/S/L, on the right.

The origin of the Novocomum project is to be found in the desire to complete a trapezoidal city block after work on a residential building designed by the architect Giacomo Caranchini (fig. 1) had been interrupted. The existing structure at this point was a C-shaped building of five floors above ground, with facades "characterised by sinuous lines inspired by late Secessionism" [10], complete with oriel windows at the corners and pitched roofs. The ideas that inspired Terragni's design were entirely different, and so innovative that the completed building dumbfounded the unhappy citizens of Como and the local authorities.

By the end of 1927 Terragni was at work on the project, producing various designs that can 
be grouped in four main versions (fig. 2). The first "floorplan study" [11] reveals the initial ideas for the project: the $\mathrm{C}$-shaped structure develops around the slightly projecting volume of the central staircases and the two trapezoidal staircases located at the internal corners of the building, with the apartments laid out along a central corridor.

In the first version of the project, dated January 1928, the weight-bearing structure comprised brick walls of a certain thickness, whilst columns of reinforced concrete supported the two staircases giving access to the basement. There were two solutions for the distribution of access to the building: the first involved four staircases (the two in the corners and two in the central block); the second involved the creation of three staircases and is comparable with that finally adopted.

A second version of the project is dated May 1928. Luigi Zuccoli, who worked with Terragni for years, would later write that this version, presented to Como City Council on 23 May [12], was deliberately outlined using drawings different to the solution ultimately adopted in order to facilitate approval by the Council's Building Committee [13].

On 30 May authorization was requested to erect fencing around the site. [14] Work began on 8 June and ten days later the Podestà sent a letter [15] to the engineer Ezio Peduzzi of the Società Novocomum to inform him that authorisation of the beginning of work was provisional upon the elimination of the intermediate floor envisaged within the structure, and the

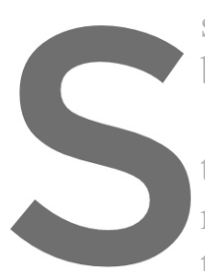
submission of plans

building permits.

The third version of

the structure compris

main staircase wells,

the eagerness with whic
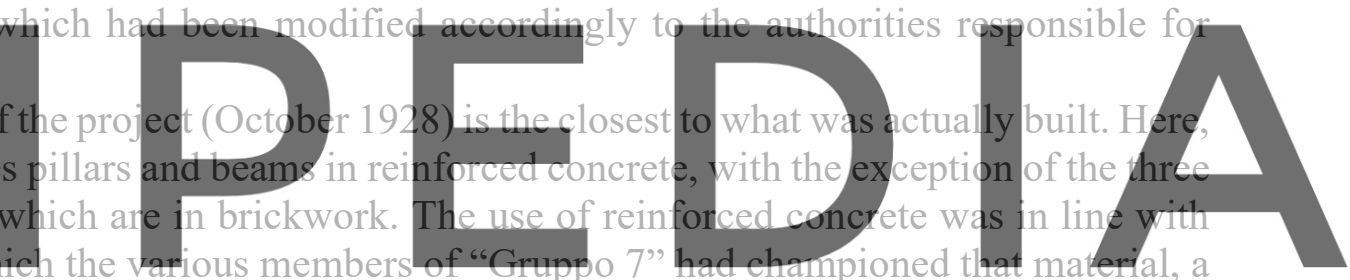

stance which in turn reflected the enthusiasm voiced by many of the engineers, and of the

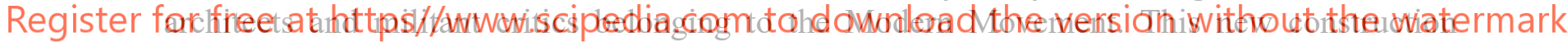

technique, it was argued, combined the properties of a composite material with high-quality structural performance and opportunities for new freedom in architectural composition [16, 17].

To return to the chronology of the project, on 10 July 1928 the Società Ghisleri, which had taken on the task of carrying out the work, had forwarded the first plan of the layout of the concrete pillars, so that the architect could then draw up definitive working designs. On 2 August the company then sent the structural project designs to the Prefecture, which would on 23 August send then back as failing to meet ministerial guidelines. Only on 10 October 1928 would authorisation be granted for the structures in reinforced concrete. At the same time, the authorities also requested the submission of definitive designs, which would be the abovementioned drawings and plans of October 1928. 

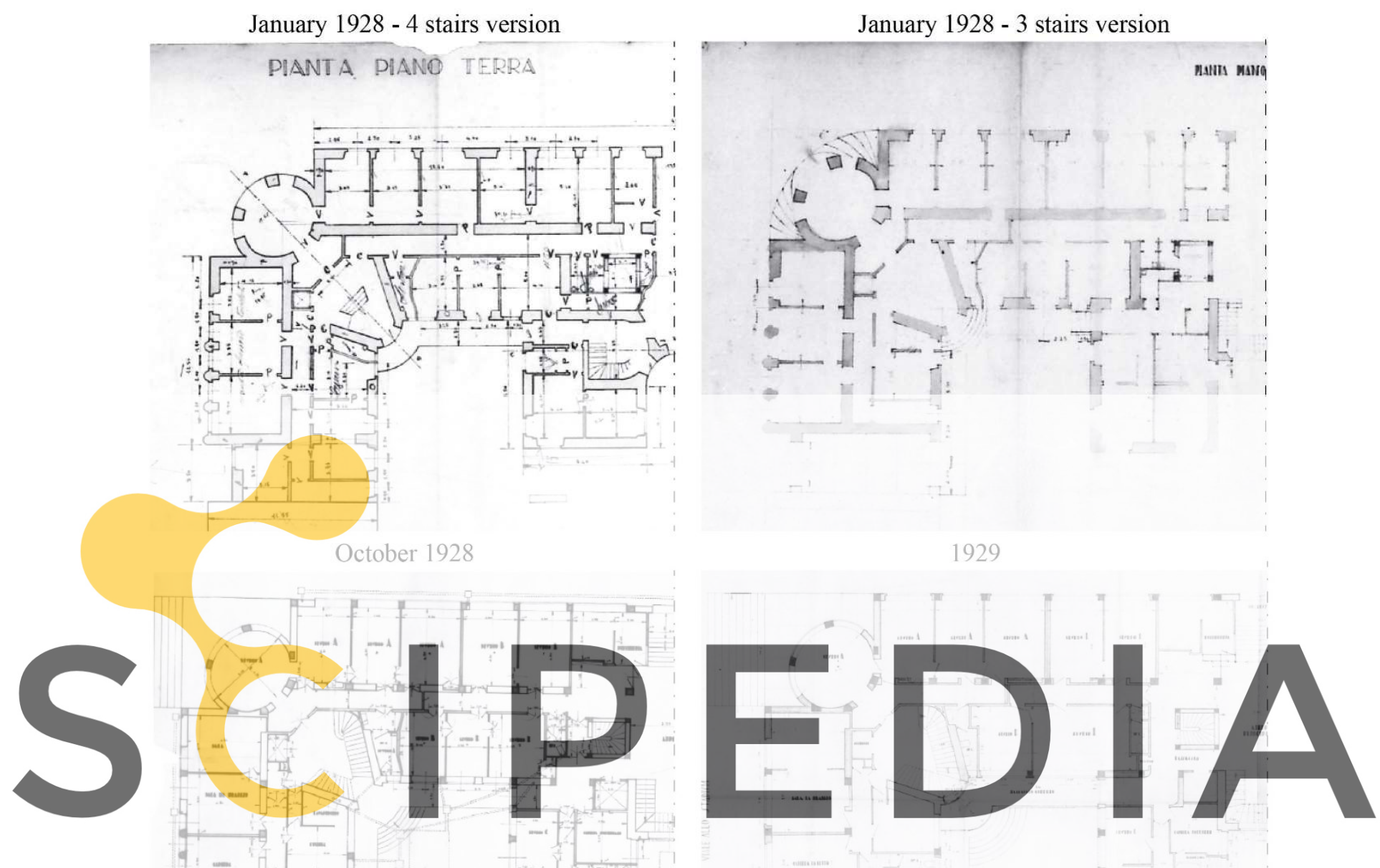

Register for free at https//www.scipedia.com to download the version without the watermark

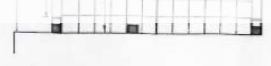

Figure 2: Project designs for Novocomum. Ground plans for the raised/ground floor in the various versions of the project (ATCo).

\section{A MIXED STRUCTURE}

Even before implementation of the plans for the structure had been authorised, behind the wooden fencing around the site work began on casting the cement for the building's foundations. On 12 December 1928 the structures for the basement, raised floor and first floor seem to have been completed, given that on that day work began on casting the floor between the first and second storeys [12].

Documentation from the worksite provides apparently contradictory information. It would seem that from 22 December 1928 to 28 February of the following year work on the concrete components had to be suspended due to freezing temperatures. However, the report submitted to the arbitration panel - hence a very important document - claims that the floor of the last 
storey was cast at the end of March, whilst another passage in the same document attributes the delays in proceeding with work on the reinforced structures to the lack of timber for the formwork (before proceeding to one floor, they had to wait for the dismantling of the formwork from the floor below). Furthermore, delays in submitting the full project drawings and plans had an effect on the sequence of work on site and on the rate of progress.

Overall, the reports prepared by the opposing parties for the arbitration panel depict a worksite where progress was troubled by continual disagreements and clashes between the Director of Works and the building contractors. Nevertheless, even if they portray the state of affairs from very different viewpoints, these documents provide very useful information with regard to the work carried out, the materials used and the construction methods adopted.

\subsection{The Components in Reinforced Concrete}

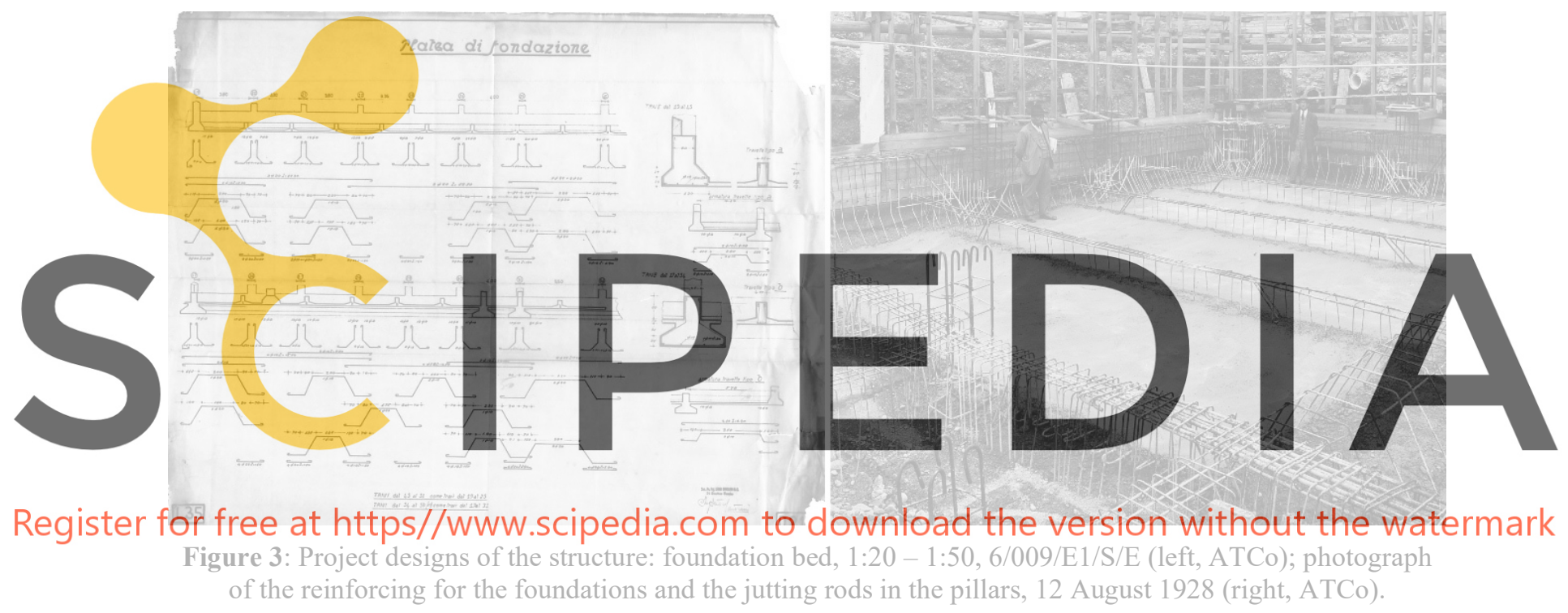

The drawings and documents relating to the execution of building work reveal that the designs of the raised structures were drawn up as work was proceeding to excavate and consolidate the site; that in the early phases of work there was as yet no design project that had been fully approved and then submitted as such to the contractors [18]. As far as the materials used were concerned, it was "first-quality man-made cement from Caluso" that was chosen, and tests were carried out on normal mortars at the Material Testing Laboratory of the Politecnico di Milano. The material chosen for the reinforcing comprised "solid round rods of homogeneous iron, without any imperfections"; these were to be smooth and of a diameter that varied from 14 to $20 \mathrm{~mm}$. After a seasoning of 28 days, the resistance to compression was $595 \mathrm{~kg} / \mathrm{cm}^{2}$ (certificates n. 4210-4211, 9 August 1928). The sand and gravel used in the cement mix were fully in compliance with the prescriptions laid down in art. 6 and 7 of chap. II, second part of the law decree 1431 of 7 June 1928 ("Prescriptions for the approval of hydraulic agglomerates and for the execution of work in cement conglomerates"). The proportions of aggregate/cement were $0,40 \mathrm{~m}^{3}$ of sand and $0,80 \mathrm{~m}^{3}$ of gravel per $300 \mathrm{~kg}$ of cement [19]. 


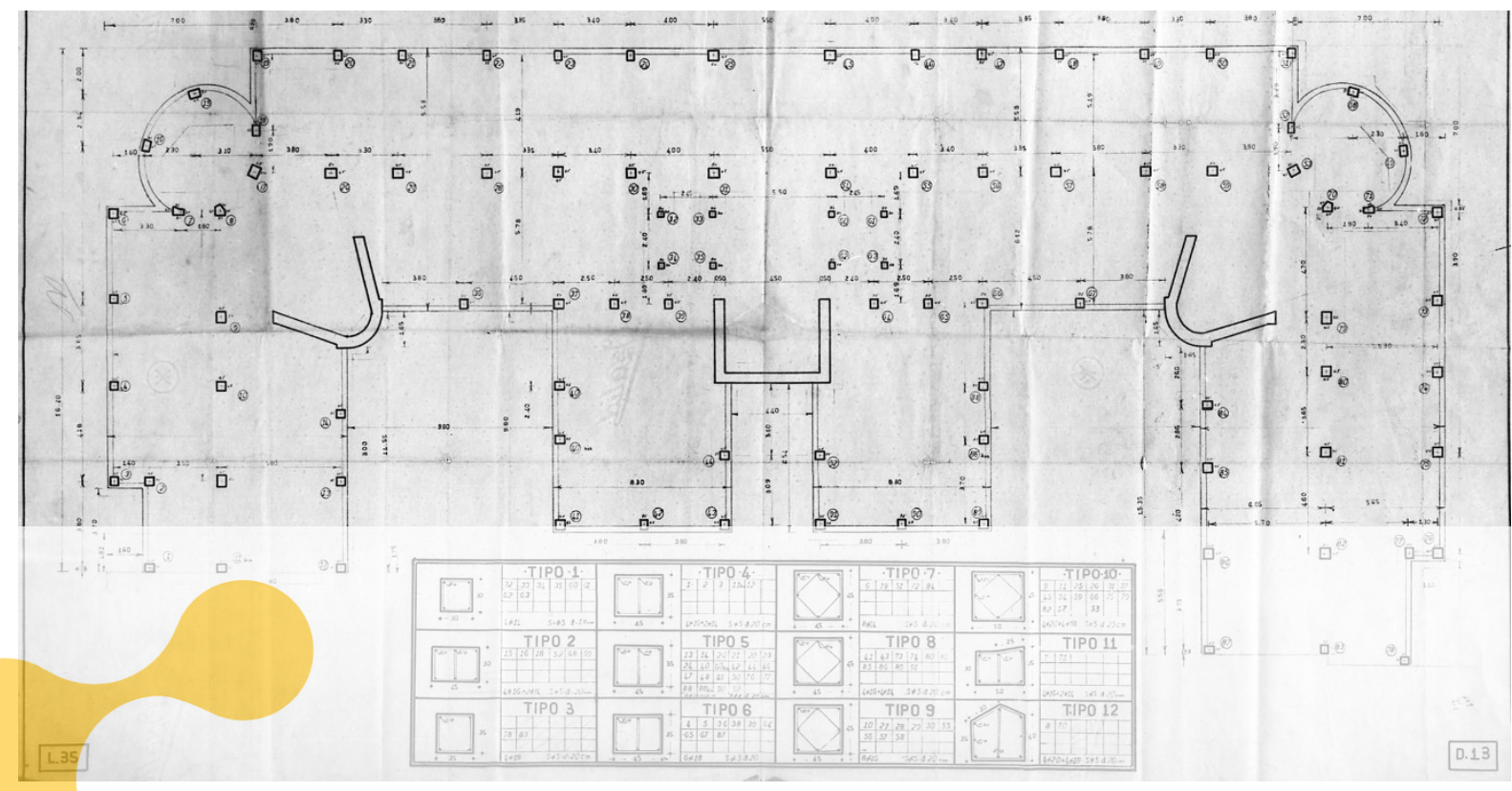

Figure 4: Groundplan of the basement with the abacus of the pillars, 1:50, 6/011/E1/D/E FTGR. 1 and 2 (ATCo).
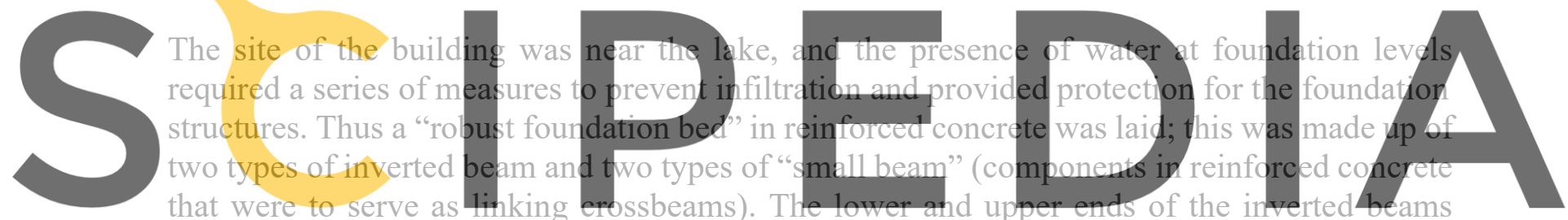

were, respectively, 120 and 60 centimetres below the perimetral pillars, and $45 \mathrm{cms}$ below the

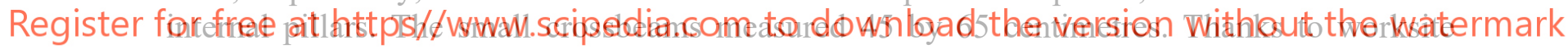
photographs (fig. 3) one can see the dense weave of reinforcing rods in the inverted beams of the foundation.

Through comparison of the details regarding the execution of the foundation bed (fig. 3), the plan of the pillars in the basement (fig. 4), the structural report for the arbitration panel and onsite photographs, it was possible to develop a virtual reconstruction of the structure in reinforced concrete that was created (fig. 5). This could be done by analysing the position of each pillar and assuming the entire structure to have been symmetrical around a supposed axis running through the entrance atrium.

The floor plan of the basement (fig. 4) shows that the system of pillars, of twelve different types (varying in shape and size), was designed to be adapted to the layout and development of the walls. Also the statics calculations were carried out following the rules laid down in art. 17 and 18 of the Royal Law Decree 1431 of 7 June 1928. Armor brackets were to be placed at a distance equal to ten times the diameter of the longitudinal reinforcing rods, with the exception of some pillars where there were to be double lattice brackets. [18] The bases of the pillars were mainly square or rectangular in section, with the exception of those used in the corner cylindrical structures, which were polygonal in base section. In the structural report it is stated that the designs included no pillars of a section less than $25 \times 35 \mathrm{~cm}$, "so as to avoid problems 
with column loads".

The sizing of the beams distinguishes between the perimeter beams - of base $45 \mathrm{~cm}$ and height $40 \mathrm{~cm}$ - and the rooftree beams (base: $45 \mathrm{~cm}$; height: $56 \mathrm{~cm}$ ). The beams were created with a "countersink" at the point where they met the pillars, which was then concealed within the walled structure. This detail, which can be made out in the worksite photographs now in the Terragni archives, appears to be very similar to something one sees in the Hennebique system: "a characteristic feature [of which] is the link between pillars and beams, which often involves inclined brackets near their point of support." [20].

In accordance with the final plans and designs there were three staircases to the upper floors, right up to the roof. All of these gave onto the internal courtyard and comprised projecting ramps of steps. The solid slabs in reinforced concrete were cast on site, and the bond-beam was inserted into the weight-bearing walls, which were five bricks thick (fig. 7). Between the basement and the raised floor level there were two staircases in reinforced concrete. From the basement level to street level there was a ramp (again in reinforced concrete) that opened into the internal courtyard in correspondence with the central block of the building.
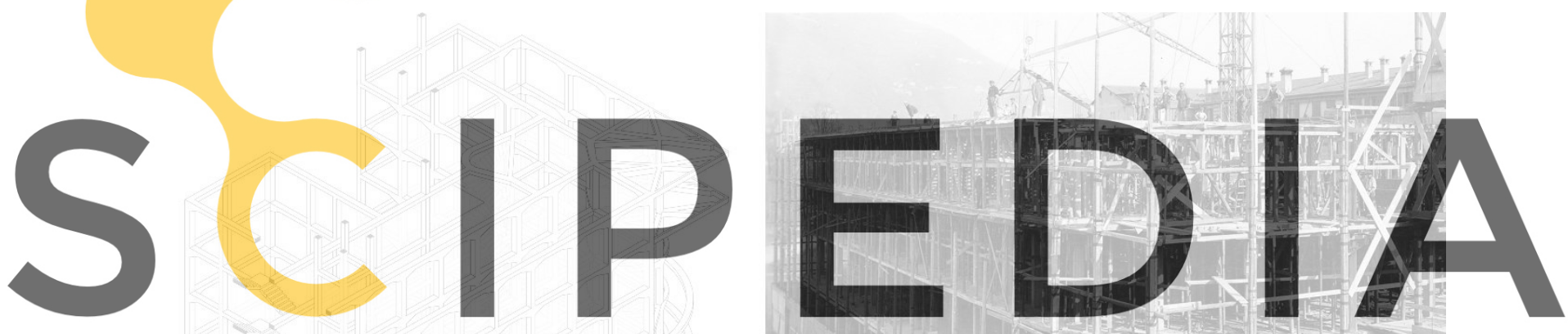

Register for free at https//www.scipedia.com

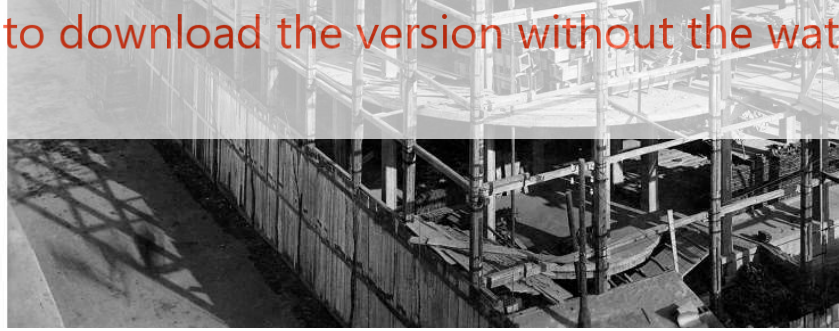

Figure 5: 3D reconstructions of the skeletal framework in reinforced concrete (left); photograph of the structures in reinforced concrete (right, ATCo).

\subsection{The Walls}

The documents relating to the materials used are here incomplete. We know that for the masonry veneer work and the internal partition walls, hollow bricks were used; whilst for the weight-bearing walls of the stairwells - which were pierced by windows from the ground floor up to the level of the roof - it was solid bricks that were used. 

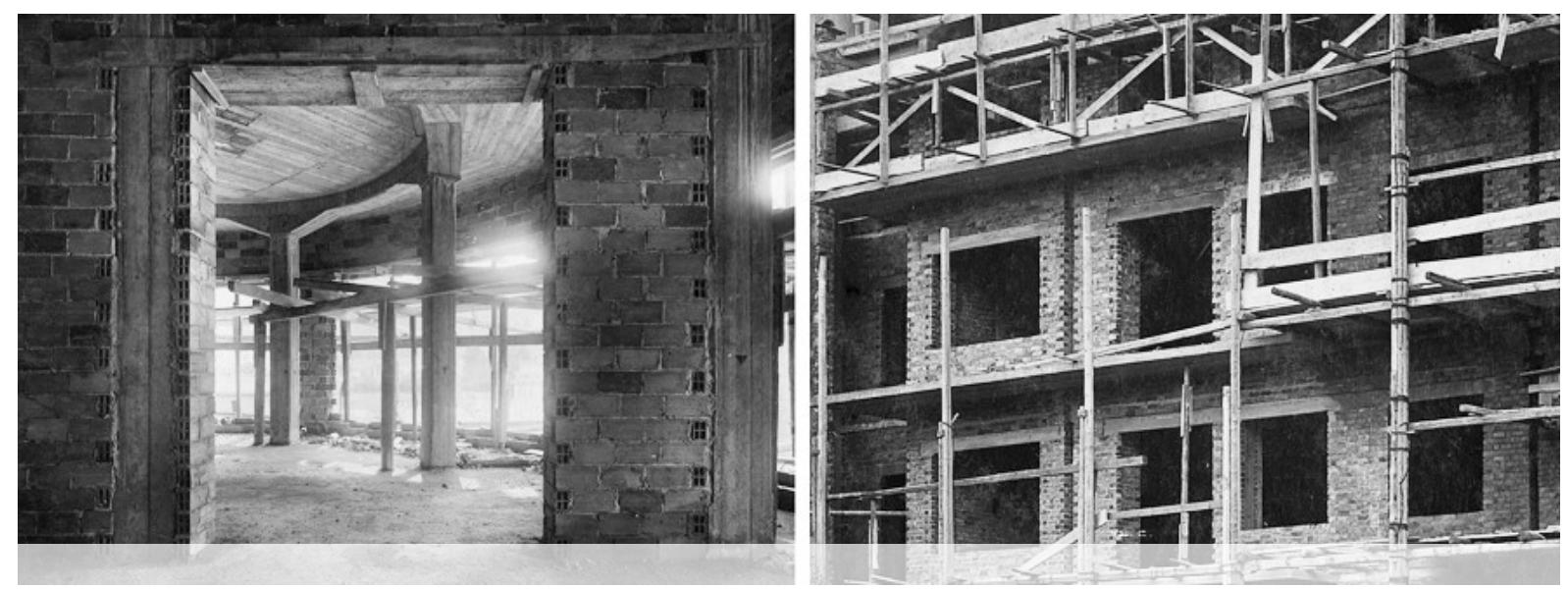

Figure 6: Novocomum under construction: one can see the outside and internal walls in perforated brick (ATCo).

As regards hollow bricks, Terragni would use Frazzi bricks in his Casa del Fascio; we can also find advertisments by the Frazzi company of Cremona, which produced bricks of similar size to those used in Novocomum in some architectural magazines such as 'Edilizia Moderna' and 'Quadrante'.

The on-site photographs (fig. 6), as well as the documents submitted to the arbitration pand between Società Ghisleri and the Novocomun, show the bricks used for the outside have had four perforations in them, whilst for parts of the walls of the corner cylinders

perforation bricks were used to face the pillars. The overall thickness of the external nonbearing walls of Novocomum is $57 \mathrm{~cm}$. Further information can be gleaned from the technical notes to be found in Luigi Figini's article entitled Una casa (1930), where it is specified that

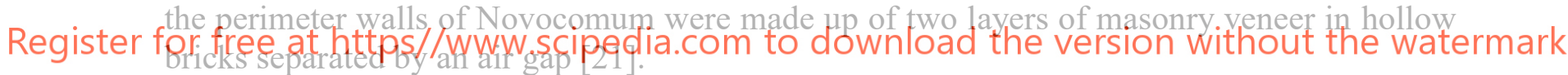
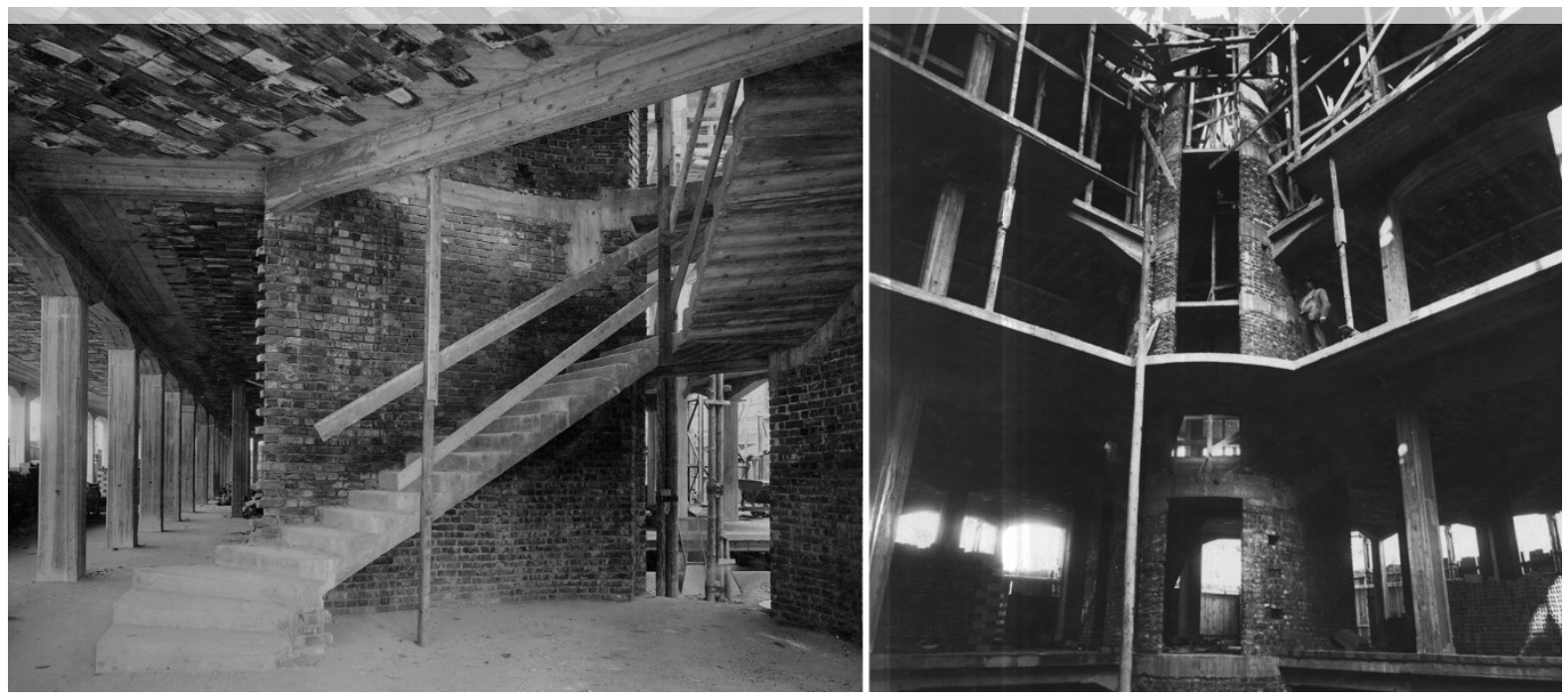

Figure 7: Novocomum. Worksite photographs showing the stairwells with walls of solid brick (ATCo). 
Indirect confirmation of the systems described by Figini can be found in Griffini's textbook [22], and in various other structures built in the 1930s (including Terragni's own Casa del Fascio).

\subsection{The Floors between Storeys and the Roofing}

The floors of the building were created in hollow-core concrete, that is, hollow bricks and beams of reinforced concrete cast on site. Here, too, thanks to on-site photographs (fig.8) one can see that the reinforcing rods of the beams were fitted into brick ends. The project defined the "spans" delimited by the beams, with specific characteristics depending on the greater or lesser distance between the pillars. The graphic reconstruction of the structure brought out the similarities and differences that exist between the floors in the various parts of the building. In some "spans" the planned floor was to have an overall thickness of $20 \mathrm{~cm}$. This comprised a 5$\mathrm{cm}$ slab of reinforced concrete with hollow-block bricks to a depth of $15 \mathrm{~cm}$ : these blocks were laid in pairs, whilst at the edges (near the beams) they were laid singly. In other open spans the floor was designed to be $23 \mathrm{~cm}$ in thickness: a $5-\mathrm{cm}$ concrete slab and $18 \mathrm{~cm}$ of hollow-block bricks. These were either laid out in pairs, with the end bricks next to the concrete beams laid singly, or in groups of 8, with the end bricks in groups of 4 [18]. In the absence of exhaustive records, we proceeded by approximation, supposing the structure to be symmetrical - that is, that the solution proposed for the west side of the building was like that used for the east side. Similarly, it was supposed that one solution was standard for other "spans" in the parts that did not exist on

The flooring of the last storey - in particu reconstructed by comparing executive drawings, for the arbitration panel and finally found evidence in a technical description and related illustration published by engineer Candiani (Ghisleri company). [23] Novocomum's "weight-
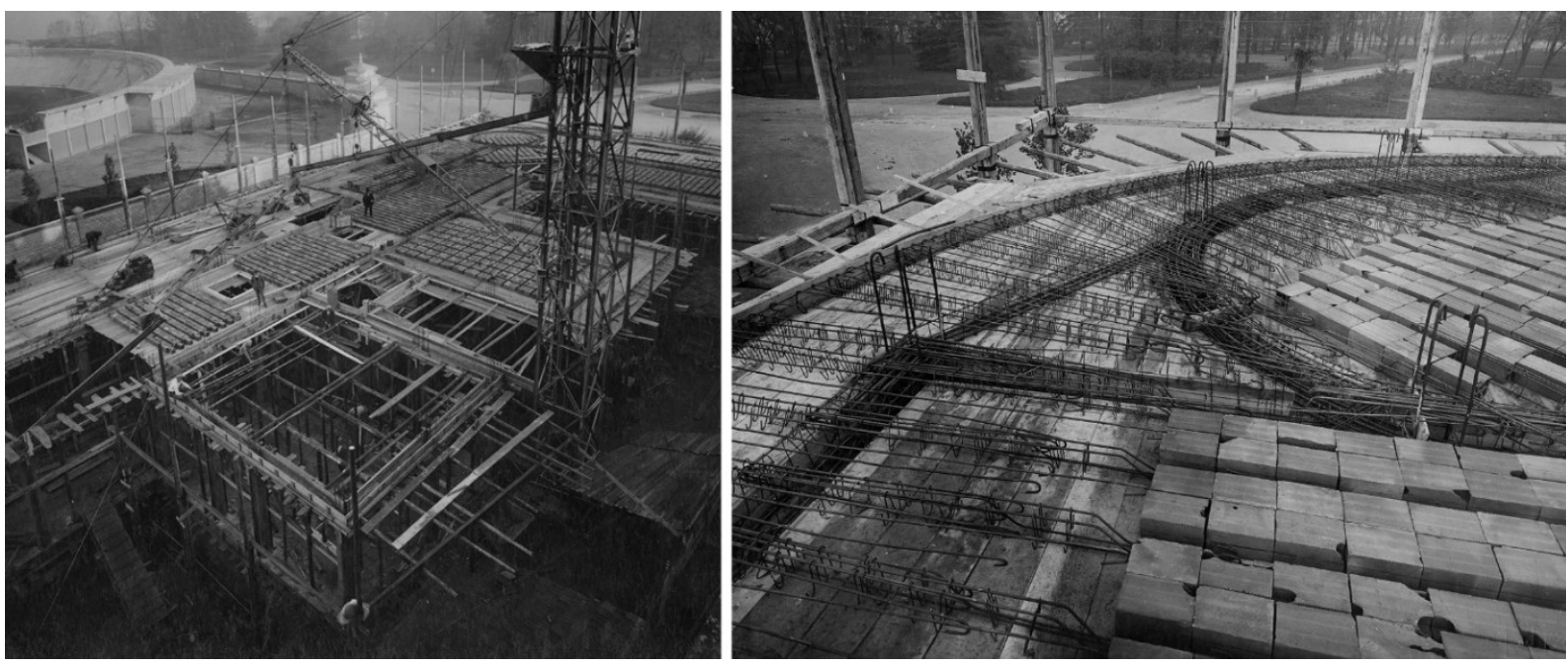

Figure 8: Novocomum. Worksite photographs showing the floors of the building in hollow-core concrete (ATCo). 


\section{CONCLUSIONS}

In October the scaffolding and worksite fencing around Novocomum came down, and the building finally became visible. Echoing protests by numerous citizens of Como, the local newspaper «La Provincia» published an article that lambasted a structure which it nickname "the ocean liner" and described as "ugly ... and in bad taste" [24]. The city authorities declared themselves surprised, saying that the final building did not correspond to the plans that had been approved by the Building Committee, and on 9 December 1929 set up a commission to decide whether Novocomum "was a feature that disfigured the area, and, if so, what measures might be taken to make it fit in better with the surrounding environment" [25]. As is wellknown, the members of that commission - Piero Portaluppi, a planner and a professor at the Politecnico di Milano; Giovanni Greppi, a Milanese architect who also worked in the Como area; Luigi Perrone, a state functionary at the Soprintendenza ai Monumenti della Lombardia [Superintendence for Preservation of Lombardy's Monuments] - ultimately decided in favour of keeping as it had been completed a building which would soon be said to mark "the birth of a new aesthetics, a new way of living; a new way of envisaging housing [...] It will, for everyone, become 'home', the 'house of tomorrow'." [26]

Nowadays, Novocomum is recognised as one of the great examples of twentieth-century architecture, even if in the 90 years since its completion the structure has undergone various alterations - both before and after it became a listed building on 17 November 1986. These changes have gradually and noticeably altered the internal appearance and layout of the building, even if the demolition, shifting and replacement of various partition walls does not seem to have compromised the weight-bearing structure.

By reconstructing the history of the construction process itself, it was possible to get a first outline of the material history of a building which is one of the various examples of a "mixed structure" created in this period; in the case of Novocomum, this was the result of an eightmonth sequence of changes to the project, leading to the replacement of a brick-wall weightbearing structure with one in pillars and beams of reinforced concrete (brick walls ultimately only figuring in the stairwells). The knowledge generated by this research provides a useful basis for studies of the structural behaviour of the building and for planning the maintenance work necessary to preserve a monument of twentieth-century architecture.

\section{REFERENCES}

[1] Griffini, E. Costruzione razionale della casa. I nuovi materiali. Orientamenti attuali nella costruzione, la distribuzione, la organizzazione della casa. Hoepli (1932), p.VII.

[2] Poretti, S. Modernismi italiani. Architettura e costruzione nel '900. Gangemi (2008), p. 11.

[3] Terragni's studio Archive, Project File for the Como City Council, Project Report, (13 May 1928).

[4] Zevi, B. Edificio ad appartamenti "Novocomum", Como. In: Giuseppe Terragni. Zanichelli, (1980), pp.24-26.

[5] Fosso, M. and Mantero, E. Giuseppe Terragni 1904-1943. Cesare Nani, (1982), pp.56-57, $82-85$. 
[6] Vitale, D. in: Cavalleri, G. and Roda, A. Novocomum. Casa d'abitazione. Nuove parole (1988), pp.9-46, 81-132, 165-178.

[7] Vitale, D. Edificio ad appartamenti Novocomum a Como. In: Ciucci, G. (ed.): Giuseppe Terragni. Opera completa. Electa (1996), pp.315-321.

[8] Schumacher, T. L. Dal Novecento al razionalismo. In: Giuseppe Terragni. 1904-1943, Electa Mondadori (1992), pp.71-84.

[9] Greppi, A. and Facchi, A. Il Novocomum di Giuseppe Terragni alla prova del tempo. Costruzione, trasfromazioni, tutela, restauro. Masters degree thesis in Architecture, academic year 2016-2017, Politecnico di Milano, supervised by Carolina Di Biase and Camilla Casonato.

[10] Longatti, A. Tra Eclettismo e Razionalismo. Contributo monografico di approfondimento storico al Piano delle Regole del Comune di Como (2013), p. 376.

[11] Terragni's studio Archive, 6/025/B1/S/L, Study of the floor plan.

[12] Terragni's studio Archive, Ghisleri file for the arbitration panel, Report to the Arbitration Panel (8 July 1932).

[13] Zuccoli, L. Quindici anni di vita e di lavoro con l'amico maestro Giuseppe Terragni. Ed. C. Nani (1981), p.14.

[14] Historical municipal Archive of Como, cart. N. 575/2, P.G.11552/28, Building permit 1928, Authorization for the erection of the scaffolding (20 November 1928).

[15] Terragni's studio Archive, Ghisleri file for the arbitration panel, Letter from the Podestà of Como to the engineer Ezio Peduzzi (18 June 1928).

[16] Gruppo 7 (Figini, L., Frette, G., Larco, S., Libera, A., Pollini, G., Rava, C.E. and Terragni G.,). Architettura IV. Una nuova epoca arcaica, Rassegna Italiana: politica, letteraria e artistica (May 1927), XIX-CVIII-II:467-471.

[17] Gruppo 7. Architettura IV. Quadrante (April 1935), 24:22-24.

[18] Terragni's studio Archive, Ghisleri file for the arbitration panel, Comments accompanying the list of project drawings (25 July 1932).

[19] Terragni's studio Archive, Ghisleri file for the arbitration panel, Structural Report (s.d.)

[20] Nelva, R. and Signorelli, B. Avvento ed evoluzione del calcestruzzo armato in Italia: il sistema Hennebique. Edizioni di scienza e tecnica (1990), p.16.

[21] Figini, L. Una casa. Natura (January 1930) 1:47-52.

[22] Griffini, E. Costruzione razionale della casa. Hoepli (1947) (1 ed. 1932), pp. 94-95.

[23] Candiani, S. Rubrica tecnica. Strutture mensolari a intradosso piano. Rassegna di Architettura (15 December 1931) 12:473-476.

[24] Editorial. Edilizia pubblica e pubbliche proteste. La Provincia di Como. Il Gagliardetto (13 October 1929).

[25] Editorial. Una commissione per giudicare il transatlantico di Campo Garibaldi. La Provincia di Como. Il Gagliardetto (19 December 1929).

[26] Pagano, G. I benefici dell'architettura moderna (A proposito di una nuova costruzione a Como). La Casa Bella (March 1930) 27:14. 